agriTECH, 40 (3) 2020, 254-261

\title{
Karakteristik Growol yang Dibuat dengan Variasi Varietas Ubi Kayu (Manihot esculenta Crantz) dan Lama Fermentasi
}

\author{
Characteristics of Growol Made with Different Cassava Varieties and Fermentation Time \\ Sandi Afrianto, Chatarina Wariyah* \\ 1Program Studi Teknologi Hasil Pertanian, Fakultas Agroindustri, Universitas Mercu Buana Yogyakarta, \\ Jl. Wates Km. 10 Yogyakarta 55244, Indonesia \\ *Penulis korespondensi: Chatarina Wariyah, E-mail: wariyah@mercubuana-yogya.ac.id
}

Tanggal submisi: 28 September 2019; Tanggal penerimaan: 18 Maret 2020

\begin{abstract}
ABSTRAK
Growol merupakan makanan pokok yang terbuat dari ubikayu dan diolah melalui proses fermentasi, pencucian, pengepresan, pencacahan, dan pengukusan. Growol potensial sebagai pangan fungsional karena mengandung bakteri asam laktat yang bermanfaat bagi kesehatan. Permasalahannya adalah pengrajin sering membuat growol menggunakan campuran berbagai varietas ubi kayu dengan lama fermentasi yang bervariasi. Padahal komposisi setiap varietas ubikayu utamanya kandungan pati tidak sama, selain itu fermentasi dilakukan untuk waktu yang tidak pasti dan berkisar antara 2-4 hari. Lama fermentasi menentukan citarasa khas masam dan total bakteri asam laktat growol. Penelitian ini bertujuan untuk mengevaluasi penggunaan varietas ubikayu dan lama fermentasi terhadap karakteristik kimia dan total bakteri asam laktat (BAL) serta tingkat kesukaan growol. Penelitian ini menggunakan varietas ubikayu jenis Meni, Ketan, dan Lanting dengan variasi lama fermentasi 2 dan 4 hari. Setiap sampel ubikayu dan hasil fermentasi dianalisis kadar air, pati, dan amilosa. Selanjutnya fermented cassava yang telah dicuci dan dipress, dikukus selama 15 menit. Growol yang dihasilkan dianalisis kadar air, $\mathrm{pH}$, keasaman tertitrasi, total bakteri asam laktat (BAL) serta tingkat kesukaannya menggunakan metode hedonic test. Hasil penelitian menunjukkan bahwa kadar pati varietas ubikayu tidak berbeda nyata, namun lama fermentasi mempengaruhi kadar air, amilosa, keasaman tertitrasi, jumlah BAL, dan kesukaan growol. Growol yang disukai adalah growol yang dibuat dari ubikayu varietas Meni dengan lama fermentasi 2 dan 4 hari dan varietas Ketan dan Lanting dengan fermentasi selama 2 hari. Namun berdasarkan kandungan bakteri asam laktatnya, maka sebaiknya growol dibuat dengan varietas Meni dengan fermentasi selama 4 hari. Growol tersebut memiliki karakteristik kadar

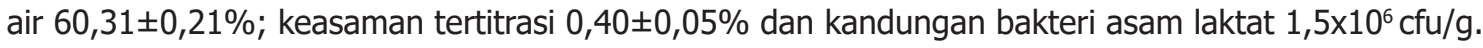

Kata kunci: Akseptabilitas; varietas-ubikayu; growol

\begin{abstract}
Growol is a staple food made from processed cassava through fermentation, washing, pressing, and chopping. It is beneficial to health due to its lactic acid bacteria content. The problem was that producers always mix different cassava varieties, and varied fermentation time. Meanwhile, each cassava has different composition, especially their starch content. The fermentation time was not constant which ranges between 2-4 days. Furthermore, the typical sour taste and lactic acid bacteria content are determined by the length of this period. Therefore, this study aimed to evaluate the effect of cassava varieties and fermentation time on the chemical properties, total lactic acid bacteria (LAB), and the preference level of growol. The cassava used in this study were Meni, Ketan, and Lanting varieties, with fermentation time ranging between 2-4 days. Each sample were analyzed to determine moisture content, starch, and amylose. Furthermore, the fermented cassava that has been washed and pressed, was
\end{abstract}


steamed for 15 minutes. Therefore, the resulted growols were analyzed to determine their moisture content, $\mathrm{pH}$, titratable acidity, total $\mathrm{LAB}$, and preference level using hedonic test method. The results showed the starch content were not significantly different, but the chemical properties was affected by the fermentation time (moisture content, amylose, titratable acidity), total LAB and preference level. Furthermore, the acceptable growols were made from Meni variety with fermentation time ranging between 2-4 days, or Ketan and Lanting varieties with 2 days fermentation. However, based on the lactic acid bacteria content, growol should be made with Meni variety with 4 days fermentation process, which had moisture content of $60.31 \pm 0.21 \%$, titratable acidity of $0.40 \pm$ $0.05 \%$ and lactic acid bacteria content of $1.5 \times 106 \mathrm{cfu} / \mathrm{g}$.

Keywords: Acceptability; cassava-variety; growol

\section{PENDAHULUAN}

Growol merupakan makanan pokok khas masyarakat Kabupaten Kulon Progo, DIY. Growol dibuat dari ubi kayu yang difermentasi, sehingga menghasilkan aroma dan rasa yang khas yaitu asam (Bangsa, 2015). Tahap-tahap pengolahan growol meliputi: pengupasan ubi kayu, pengirisan, perendaman (fermentasi spontan) selama 3-5 hari, pencucian dan pemisahan serat ubi kayu, pengepresan, penggilingan dan pengukusan (Wariyah dan Luwihana, 2015). Growol memiliki potensi sebagai pangan fungsional, dalam hal ini pangan fungsional probiotik, karena growol mengandung bakteri asam laktat. Dalam growol, bakteri asam laktat yang dominan tumbuh selama proses perendaman ubikayu adalah L. plantarum dan L. casei subsp. Rhamnosus (Putri dkk., 2012). Lactobacillus dalam fermented cassava yang direndam selama 48 jam sebanyak

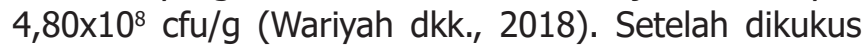
selama 15 menit growol yang diolah dengan fermentasi selama 48 jam kandungan bakteri asam laktat sebanyak $1,0 \times 10^{5} \mathrm{cfu} / \mathrm{g}$. Probiotik adalah organisme hidup yang dapat memberikan pengaruh menguntungkan terhadap kesehatan bagi host nya ketika dikonsumsi dalam jumlah yang cukup (FAO/WHO, 2002) dan sesuai jumlah mikrobia dalam usus Syarat mikroba hidup yang harus terdapat pada produk probiotik adalah sebesar $10^{6}-10^{8}$ $\mathrm{cfu} / \mathrm{ml}$ (Shah, 2007 dalam Yuniastuti, 2014).

Terdapat beberapa varietas unggul ubikayu yang digunakan untuk industri pangan antara lain Ketan kulit merah atau Meni, Ketan dan Lanting (Anonim, 2017). Menurut (Susilawati dkk., 2008), ubikayu dengan varietas serta umur panen yang berbeda, kadar pati dan komponen dalam ubikayu lainnya tidak sama. Kadar pati setiap jenis ubikayu berkisar antara 13,94\% sampai $19,79 \%$ tergantung pada kondisi pertumbuhan. Demikian pula umur ubikayu, terdapat umur optimum yang memberikan kadar pati optimal, seperti varietas Kasetsart yang dipanen pada umur 7 - 10 bulan, kadar pati antara $14,33 \%$ - 35,93\% dan amilosa antara $12,37 \%-18,91 \%$.
Permasalahannya adalah pengrajin growol umumnya membuat growol dengan bahan dasar campuran berbagai varietas ubikayu dan dengan tingkat ketuaan yang bervariasi. Padahal pati merupakan substrat enzim amilase yang dikeluarkan oleh Lactobacillus selama fermentasi untuk menghasilkan asam laktat (Putri dkk., 2012). Akibatnya hasil fermentasi memberikan citarasa khas asam growol yang beragam. Masalah lain adalah para pengrajin biasanya mengolah growol dengan lama fermentasi kurang dari 4 hari dengan rata-rata 2 hari saja. Alasannya adalah pembeli growol saat ini tidak menyukai rasa asam pada growol. Untuk menghasilkan growol dengan total bakteri asam laktat (BAL) tinggi serta citarasa asam khas growol dapat dilakukan dengan fermentasi ubikayu vaietas Martapura selama 4-5 hari dan pencucian ubi kayu hasil fermentasi 2-3 kali (Wariyah dan Luwihana, 2015). Untuk itu tujuan penelitian ini adalah untuk mengevaluasi penggunaan beberapa varietas ubikayu dan lama fermentasi terhadap sifat kimia growol, total BAL serta tingkat kesukaan growol.

\section{METODE PENELITIAN}

\section{Bahan}

Penelitian ini menggunakan ubi kayu varietas lokal yaitu Meni, Ketan dan Lanting yang dibeli dari petani di desa Hargomulyo dan Kalirejo, Kecamatan Kokap, Kabupaten Kulon Progo, DIY. Ubikayu dipanen pada umur antara 8-10 bulan dan digunakan kurang dari 48 jam setelah panen. Untuk analisis kadar pati digunakan bahan kimia: $\mathrm{HCl} 25 \%$, Nelson A $\left(\mathrm{Na}_{2} \mathrm{CO}_{3}, \mathrm{KNaC}_{4} \mathrm{H}_{4} \mathrm{O}_{6} \cdot 4 \mathrm{H}_{2} \mathrm{O}, \mathrm{NaHCO}_{3}, \mathrm{Na}_{2} \mathrm{SO}_{4}\right)$, Nelson $\mathrm{B}\left(\mathrm{CuSO}_{4} \cdot 5 \mathrm{H}_{2} \mathrm{O}, \mathrm{H}_{2} \mathrm{SO}_{4}\right.$ ), dan Arsenomolibdat), kadar amilosa (Etanol absolut, $\mathrm{NaOH} 1 \mathrm{~N}, \mathrm{CH}_{3} \mathrm{COOH} 1 \mathrm{~N}$, Iod 2\%), dan analisis keasaman tertitrasi (indikator phenolphthalein dan $\mathrm{NaOH} \mathrm{0,1} \mathrm{M).} \mathrm{Kualifikasi} \mathrm{bahan}$ kimia pro analysis yang dibeli dari Merck. Media MRS Agar untuk pembuatan kultur bakteri asam laktat (BAL) dari Oxoid Ltd. 
Alat

Alat-alat yang digunakan meliputi: seperangkat alat untuk membuat growol (pisau, panci plastik, talenan, tambir), pengukus (Bima stainless steel), timbangan (Ohaus Triple Beam TJ2611), alat pengepress dan autoklaf (All American Model 1941 X). Peralatan gelas untuk analisis kimia dan uji mikrobiologis (cawan petri) dari Pyrex Iwaki (Iwaki glass under LIC), neraca analitik Ohaus (Model PA224, USA), inkubator (Memmert DIN 40050 IP 20), vortex (Maxi Mix II TY 37600), spektrofotometer (Shimadzu mini 1240 UV-VIS Spectrophotometer), pH- meter (Hanna HI 2210) dan peralatan untuk pengujian inderawi.

\section{Cara Penelitian}

Penelitian ini terdiri dari tahap-tahap: 1) persiapan bahan dasar, 2) pembuatan growol dan 3) analisis kimia, mikrobiologis dan tingkat kesukaan growol.

\section{Persiapan bahan dasar}

Bahan dasar yang digunakan untuk membuat growol adalah ubi kayu dengan varietas Meni, Ketan dan Lanting. Tiap varietas ubikayu dianalisis kadar air dengan metode gravimetri statis (AOAC, 1970), kadar pati dengan metode Direct Acid Hydrolysis (AOAC, 1970), analisis amilosa dengan metode colorimetri (Williams, dkk., 1970), keasaman tertitrasi (Apriyantono dkk., 1989). Tiap jenis ubikayu ditimbang sebanyak $2 \mathrm{~kg}$, kemudian dikupas dan dicuci menggunakan air mengalir sampai bersih, kemudian ditimbang dan dipotong-potong dengan ukuran sekitar $5 \mathrm{~cm}$ dan siap digunakan untuk membuat growol.

\section{Pembuatan growol}

Proses pembuatan growol melalui tahap: ubikayu dari tiap varietas (tahap 1) yang telah dipotong dengan ukuran $\pm 5 \mathrm{~cm}$, difermentasi dengan cara direndam dalam air pada suhu kamar dengan rasio ubikayu/air 1: 3 (b/v) dengan variasi lama fermentasi adalah: 2 dan 4 hari (Wariyah dan Luwihana, 2015). Ubikayu yang telah difermentasi (fermented cassava) dicuci menggunakan air bersih sebanyak 2 kali dengan rasio fermented cassava/air adalah 1: $5(\mathrm{~b} / \mathrm{v})$, tujuannya untuk menghilangkan air fermentasi sekaligus menghilangkan serat ubikayu serta kotoran yang terikut. Selanjutnya fermented cassava ditiriskan dan dipress sampai kadar air sekitar $55-60 \%$ dengan indikator tekstur pressed fermented cassava sudah pisah-pisah (mawur, Jawa) (Wariyah dkk., 2018), agar setelah dikukus dihasilkan tekstur growol yang menyerupai nasi dan tidak seperti bubur. Fermented cassava dianalisis kadar air, pati, amilosa dan gula reduksi dengan metode Nelson
Somogyi (AOAC, 1970). Pengukusan dilakukan selama 15 menit dan dimasukkan ketika air dalam pengukus mulai mendidih. Growol yang dihasilkan didinginkan pada suhu kamar, kemudian diuji derajad keasaman menggunakan $\mathrm{pH}$ meter, jumlah bakteri asam laktat dengan metode Total Plate Count (TPC) (Fardiaz, 1992) dan dan hedonic test untuk menentukan kesukaan growol (Kramer dan Twigg, 1970), dengan panelis agak terlatih sebanyak 25 orang. Skor yang digunakan adalah antara 1 sampai 7, dengan nilai 1 untuk kategori sangat suka dan 7 untuk kategori sangat tidak suka (Setyaningsih, dkk. 2010).

\section{Rancangan Percobaan}

Penelitian ini menggunakan Rancangan Acak Lengkap dengan dua faktor yaitu varietas ubikayu dan lama fermentasi. Beda nyata antar perlakuan ditentukan dengan uji $F$, kemudian perbedaan antar sampel ditentukan dengan DMRT atau Duncan's Multiples Range Test. Data diolah menggunakan SPSS 13 for window.

\section{HASIL DAN PEMBAHASAN}

\section{Karakteristik Ubikayu}

Ubikayu yang digunakan untuk penelitian adalah varietas lokal jenis Meni, Ketan dan Lanting. Varietas ubikayu yang digunakan untuk penelitian ini memiliki rasa tidak pahit dan umum digunakan untuk industri makanan. Varietas Ketan dan Meni memiliki rasa enak dan hanya dibedakan pada warna kulitnya (Anonim, 2017). Varietas Meni disebut juga Ketan kulit merah sesuai warna kulitnya.

Hasil analisis kadar air, pati, dan amilosa pada ubi kayu disajikan pada Tabel 1. Dari Tabel 1 tampak bahwa kadar air tiap varietas ubi kayu berbeda nyata, sedangkan pati dan amilosa tidak berbeda nyata. Menurut (Susilawati dkk., 2008), umur panen, lingkungan pertumbuhan berpengaruh terhadap kadar air, pati maupun amilosa ubi kayu. Ubikayu varietas Ketan dibeli dari daerah Kalirejo, sedangkan Lanting dan Meni berasal dari Hargomulyo, Kokap, Kulon Progo. Diperkirakan terdapat perbedaan kondisi tempat tumbuh mengakibatkan kadar air tidak sama. Menurut (Ariani dkk., 2017), kadar air ubikayu antara 50-80\% tergantung varietas, waktu panen dan musimnya. Panen yang terlalu muda kadar air ubikayu tinggi, sedangkan kadar pati rendah. Kadar air ubikayu lebih tinggi kalau dipanen pada musim basah. Kandungan pati ubi kayu varietas Meni, Ketan, dan Lanting tidak berbeda secara nyata, demikian pula kadar amilosa. Kadar pati setiap jenis ubikayu berbeda yaitu antara 13,12\% sampai $46,09 \%$ tergantung pada kondisi pertumbuhan 
(Murtiningrum dkk., 2018). Menurut (Amarullah, 2016), kadar pati varietas Ketan antara 28,85 \%. Kadar amilosa ubikayu juga tidak berbeda nyata dan menurut (Augustyn dkk., 2007), kadar amilosa ubikayu antara 22,37-30.16\%.

Tabel 1. Kadar air, pati, dan amilosa pada ubi kayu

\begin{tabular}{lccc}
\hline Varietas & Kadar Air (\%)* & Pati (\%)** & Amilosa (\%)** \\
Meni & $64,52 \pm 0,05^{\mathrm{c}}$ & $30,19 \pm 3,43$ & $27,62 \pm 1,55$ \\
Ketan & $62,58 \pm 0,71^{\mathrm{b}}$ & $35,86 \pm 2,21$ & $31,27 \pm 0,97$ \\
Lanting & $52,68 \pm 0,13^{\text {a }}$ & $35,61 \pm 2,53$ & $32,76 \pm 3,38$ \\
\hline
\end{tabular}

* Huruf yang berbeda dibelakang angka pada kolom yang sama menunjukkan berbeda nyata pada $a=0,05$.

** tidak signifikan.

\section{Karakteristik Fermented Cassava}

Ubi kayu yang telah difermentasi dan dicuci kemudian dipress, karakteristik kimia disajikan pada Tabel 2.

Tabel 2 menunjukkan bahwa kadar air fermented cassava berbeda nyata. Ubikayu varietas Lanting dengan fermentasi selama 2 hari kadar airnya paling rendah, sedangkan pada sampel dengan lama fermentasi 4 hari relatif tidak berbeda. Ubikayu varietas Lanting sebelum difermentasi memiliki kadar air yang paling rendah, dan ternyata perendaman selama 2 hari tidak meningkatkan kadar air seperti pada sampel lainnya.

Pada Tabel 2 juga tampak bahwa kadar pati fermented cassava ubi kayu varietas Meni, Ketan dan Lanting tidak berbeda secara nyata, sedangkan kadar amilosa berbeda nyata. Terjadi kenaikan kadar amilosa fermented cassava masing-masing varietas ubi kayu seiring bertambahnya lama waktu fermentasi. Menurut (Putri dkk., 2012), selama fermentasi ubikayu pada pengolahan growol terjadi peningkatan kadar amilosa disebabkan karena Lactobacillus yang tumbuh selama fermentasi bersifat amilolitik hidrolitik yang akan menghidrolisis pati, sehingga meningkatkan amilosa. Jumlah amilosa yang terbentuk tergantung dari jenis Lactobacillus yang tumbuh, dan semakin lama fermentasi amilosa semakin tinggi, namun selanjutnya akan terpecah menjadi gula kemudian asam. Pada lama fermentasi 2 dan 4 hari terjadi penurunan kadar gula reduksi fermented cassava varietas Meni, Ketan, dan Lanting. Hal ini disebabkan karena terjadinya perubahan biokimiawi yaitu hidrolisis pati menjadi gulagula sederhana utamanya gula reduksi akibat aktivitas bakteri asam laktat amilolitik seiring lama fermentasi.

Varietas ubikayu juga berpengaruh nyata terhadap kadar gula reduksi fermented cassava. Ubikayu varietas Meni yang kadar air tinggi menghasilkan lebih banyak gula reduksi daripada varietas Ketan maupun Lanting. Menurut (Zhu dkk., 2017), hidrolisis pati secara enzimatis dipengaruhi oleh kadar air bahan, dan pada kadar air tinggi hidrolisis lebih cepat, disebabkan tidak terjadinya akumulasi partikel yang dapat menghambat hidrolisis. Oleh karena itu pada varietas Meni jumlah pati setelah difermentasi lebih rendah dan gula reduksi paling tinggi. Selanjutnya gula reduksi akan terpecah menjadi asam-asam organik utamanya asalm laktat yang dapat meningkatkan keasaman growol seperti pada Tabel 3.

Hasil analisis keasaman dan pengukuran $\mathrm{pH}$ fermented cassava dari ubi kayu varietas Meni, Ketan, dan Lanting disajikan pada Tabel 3.

Berdasarkan Tabel 3 tampak terjadi perubahan $\mathrm{pH}$ pada fermentasi 2 dan 4 hari. Pada fermented cassava ubi kayu varietas Meni, Ketan, dan Lanting, pH pada fermentasi 2 hari berturut-turut adalah 5,23; 5,65; dan 5,17 . Pada fermentasi 4 hari terjadi kenaikan $\mathrm{pH}$ pada fermented cassava ubi kayu varietas Meni, Ketan, dan Lanting berturut-turut menjadi 5,62; 5,69; dan 5,31. Selama proses fermentasi bakteri yang berperan yaitu bakteri asam laktat menghasilkan produk metabolisme

Tabel 2. Kandungan pati, amilosa, dan gula reduksi pada fermented cassava

\begin{tabular}{lccccc}
\hline Varietas & $\begin{array}{c}\text { Fermentasi } \\
(\text { hari })\end{array}$ & $\begin{array}{c}\text { Kadar air } \\
(\% \mathrm{bb})^{*}\end{array}$ & $\begin{array}{c}\text { Pati } \\
(\% \mathrm{bk})^{* *}\end{array}$ & $\begin{array}{c}\text { Amilosa } \\
(\% \mathrm{bk})^{*}\end{array}$ & $\begin{array}{c}\text { Gula reduksi } \\
(\% \mathrm{bk})^{*}\end{array}$ \\
\hline Meni & 2 & $58,16 \pm 0,36^{\mathrm{ab}}$ & $43,61 \pm 1,98$ & $17,92 \pm 0,18^{\mathrm{a}}$ & $0,03 \pm 0,002^{\mathrm{d}}$ \\
& 4 & $60,35 \pm 1,24^{\mathrm{b}}$ & $50,09 \pm 1,41$ & $28,77 \pm 0,90^{\mathrm{cd}}$ & $0,01 \pm 0,001^{\mathrm{a}}$ \\
\multirow{4}{*}{ Ketan } & 2 & $59,16 \pm 0,04^{\mathrm{b}}$ & $49,14 \pm 1,51$ & $21,06 \pm 0,67^{\mathrm{b}}$ & $0,02 \pm 0,001^{\mathrm{b}}$ \\
& 4 & $58,19 \pm 0,58^{\mathrm{ab}}$ & $54,12 \pm 1,13$ & $26,79 \pm 0,30^{\mathrm{c}}$ & $0,01 \pm 0,001^{\mathrm{a}}$ \\
& 2 & $55,81 \pm 0,11^{\mathrm{a}}$ & $58,24 \pm 2,59$ & $30,10 \pm 0,24^{\mathrm{d}}$ & $0,02 \pm 0,001^{\mathrm{c}}$ \\
& 4 & $59,23 \pm 0,30^{\mathrm{b}}$ & $51,17 \pm 1,40$ & $33,60 \pm 0,10^{\mathrm{e}}$ & $0,01 \pm 0,002^{\mathrm{a}}$ \\
\hline
\end{tabular}

* huruf yang berbeda dibelakang angka pada kolom yang sama menunjukkan berbeda nyata pada $a=0,05$

$* *$ tidak signifikan. 
Tabel 3. Keasaman tertitrasi dan $\mathrm{pH}$ pada fermented cassava

\begin{tabular}{lccc}
\hline Varietas & $\begin{array}{c}\text { Fermentasi } \\
\text { (hari) }\end{array}$ & $\begin{array}{c}\text { Keasaman } \\
\text { tertitrasi (\%bb)* }\end{array}$ & $\mathrm{pH}$ \\
\hline Meni & 2 & $1,84 \pm 0,05^{\mathrm{e}}$ & 5,23 \\
& 4 & $0,21 \pm 0,05^{\mathrm{ab}}$ & 5,62 \\
Ketan & 2 & $0,86 \pm 0,10^{\mathrm{c}}$ & 5,65 \\
& 4 & $0,07 \pm 0,00^{\mathrm{a}}$ & 5,69 \\
Lanting & 2 & $1,55 \pm 0,05^{\mathrm{d}}$ & 5,17 \\
& 4 & $0,36 \pm 0,00^{\mathrm{b}}$ & 5,31 \\
\hline
\end{tabular}

* huruf yang berbeda dibelakang angka pada kolom yang sama menunjukkan berbeda nyata pada $a=0,05$

yang mengakibatkan perubahan $\mathrm{pH}$. Jumlah mikrobia yang menghasilkan asam meningkat bersamaan dengan lamanya fermentasi, sehingga terjadi penurunan $\mathrm{pH}$. Nilai $\mathrm{pH}$ meningkat selama fermentasi 4 hari menunjukkan bahwa asam organik yang dihasilkan digunakan sebagai substrat oleh mikrobia yang lain (Putri dkk., 2012). Terjadinya kenaikan nilai pH berhubungan dengan turunnya nilai keasaman tertitrasi karena dimanfaatkannya asam-asam organik hasil fermentasi sebagai substrat oleh mikrobia, sehingga jumlah asam organik berkurang yang berakibat pada turunnya nilai keasaman.

\section{Karakteristik Growol}

Proses fermentasi menghasilkan senyawa-senyawa metabolit berupa asam organik sehingga menyebabkan penurunan nilai pH produk fermentasi (Afriani, 2010). Derajad keasaman atau nilai pH produk fermentasi berhubungan dengan kandungan asam yang dihasilkan dan memiliki hubungan yang terbalik dengan nilai total asam tertitrasi, karena semakin rendah nilai $\mathrm{pH}$ maka nilai keasaman tertitrasi semakin tinggi (Adesokan dkk.,
2011). Hasil analisis kadar air, keasaman tertitrasi dan pH growol disajikan pada Tabel 4.

\section{Kadar Air}

Kadar air growol menunjukkan perbedaan yang nyata terutama pada varietasnya. Wariyah dkk. (2018) mendapatkan bahwa kadar air growol yang dibuat dari varietas Martapura berkisar antara 58,01-60,03\%. Pada Tabel 4 tampak bahwa kadar air growol pada kisaran tersebut kecuali pada varietas Meni yang difermentasi selama 2 hari dan Lanting yang difermentasi selama 2 dan 4 hari. Faktor yang mempengaruhi pengikatan air dalam bahan antara lain kandungan kimia bahan dan struktur molekul (Kasaai, 2014). Perbedaan tersebut disebabkan karena pada tiap varietas kandungan kimia tidak sama, namun tetap dapat menghasilkan growol khas growol.

\section{Keasaman tertitrasi}

Keasaman tertitrasi dinyatakan sebagai jumlah asam yang terbentuk selama proses fermentasi dan dihitung sebagai asam laktat. Pada lama fermentasi 2 hari keasaman tertitrasi growol dengan ubi kayu varietas Meni, ketan, Lanting berkisar $0,07 \pm 0,00 \%$ - 0,36 $\pm 0,00 \%$. terjadi penurunan nilai keasaman growol dibandingkan fermented cassava. Hal ini diduga karena bagian dari asam laktat menguap selama proses pemanasan. Menurut (Komesu dkk., 2017), stabilitas asam laktat ditentukan oleh suhu dan waktu pemanasan. Semakin tinggi suhu dan semakin lama waktu pemanasan, semakin cepat asam laktat terdegradasi. Turunnya nilai keasaman berkorelasi dengan naiknya nilai $\mathrm{pH}$. Nilai $\mathrm{pH}$ growol dengan lama fermentasi 2 hari yang terbuat dari ubi kayu varietas Meni, Ketan, Lanting berkisar 5,59 $-6,18$ relatif tinggi dari $\mathrm{pH}$ fermented cassava.

Tabel 4. Kadar air, keasaman tertitrasi, dan pH growol

\begin{tabular}{lcccc}
\hline Varietas & $\begin{array}{c}\text { Fermentasi } \\
(\text { hari })\end{array}$ & $\begin{array}{c}\text { Kadar air } \\
(\% w b)^{*}\end{array}$ & $\begin{array}{c}\text { Keasaman tertitrasi } \\
(\% w b)^{*}\end{array}$ & pH \\
\hline Meni & 2 & $64,37 \pm 0,65^{\mathrm{c}}$ & $0,07 \pm 0,00^{\mathrm{a}}$ & 6,18 \\
& 4 & $60,31 \pm 0,21^{\mathrm{b}}$ & $0,40 \pm 0,05^{\mathrm{d}}$ & 5,60 \\
\multirow{2}{*}{ Ketan } & 2 & $59,80 \pm 0,46^{\mathrm{b}}$ & $0,14 \pm 0,00^{\mathrm{ab}}$ & 5,93 \\
& 4 & $60,19 \pm 0,43^{\mathrm{b}}$ & $0,25 \pm 0,05^{\mathrm{bc}}$ & 5,83 \\
\multirow{3}{*}{ Lanting } & 2 & $55,57 \pm 0,89^{\mathrm{a}}$ & $0,36 \pm 0,00^{\mathrm{cd}}$ & 5,59 \\
& 4 & $55,84 \pm 0,85^{\mathrm{a}}$ & $0,14 \pm 0,00^{\mathrm{ab}}$ & 5,83 \\
\hline
\end{tabular}

* huruf yang berbeda dibelakang angka pada kolom yang sama menunjukkan berbeda nyata pada $a=0,05$ 
Pada growol yang terbuat dari ubi kayu varietas Meni, Ketan, Lanting dengan lama fermentasi 4 hari keasaman tertitrasinya berkisar $0,14 \pm 0,00 \%$ $0,40 \pm 0,05 \%$. Terjadi kenaikan nilai keasaman growol dibandingkan fermented cassava. Hal ini diduga bakteri asam laktat yang ada di dalam growol masih bertahan selama proses pengukusan, sehingga hasil metabolitnya seperti asam laktat tidak banyak menguap. Lactobacillus casei subsp. Rhamnosus menghasilkan metabolit ekstraseluler yang stabil pada suhu kamar, tahan panas hingga suhu $98^{\circ} \mathrm{C}$ selama 30 menit, memiliki pH 3-8 dan dapat bertahan selama 15 menit pemanasan pada $121^{\circ} \mathrm{C}$ dan pendinginan selama 21 hari pada suhu $4^{\circ} \mathrm{C}$ (Lestari, 2009). Oleh karena itu, growol yang diproses melalui tahap pengukusan selama 15 menit pada $100^{\circ} \mathrm{C}$ dapat mempertahankan citarasa asam khas growol. Naiknya nilai keasaman berkorelasi dengan turunnya nilai $\mathrm{pH}$. Nilai $\mathrm{pH}$ growol dengan lama fermentasi 4 hari yang terbuat dari ubi kayu varietas Meni, Ketan, Lanting berkisar 5,60 - 5,83 relatif rendah dari $\mathrm{pH}$ fermented cassava.

\section{Jumlah Bakteri Asam Laktat pada Growol}

Bakteri asam laktat (BAL) amilolitik mempunyai kemampuan untuk mengubah pati menjadi asam laktat melalui proses fermentasi. BAL amilolitik yang yang dominan pada fermented cassava adalah Lactobacillus plantarum dan Lactobacillus rhamnosus (Putri dkk., 2012). Hasil uji total bakteri asam laktat (BAL) growol disajikan pada Tabel 5.

Berdasarkan Tabel 5 dapat dilihat bahwa semakin lama fermentasi dalam proses pembuatan growol, maka bakteri asam laktat (BAL) yang terkandung dalam growol semakin tinggi. Hal ini disebabkan karena selama proses fermentasi mikroba yang terdapat pada ubi kayu lebih mudah beradaptasi dengan substrat pati, sehingga selama fermentasi jumlahnya cenderung meningkat (Putri dkk, 2012). Menurut Wariyah dkk. (2018), jumlah bakteri asam laktat per gram growol

Tabel 5. Total bakteri asam laktat pada growol

\begin{tabular}{ccc}
\hline Varietas & $\begin{array}{c}\text { Fermentasi } \\
\text { (hari) }\end{array}$ & $\begin{array}{c}\text { Total bakteri asam laktat } \\
\text { (cfu/g) } \\
\text { Meni }\end{array}$ \\
\hline \multirow{4}{*}{ Ketan } & 4 & 0 \\
& 2 & $1,5 \times 10^{6}$ \\
Lanting & 4 & 0 \\
& 2 & $2,1 \times 10^{7}$ \\
& 4 & 0 \\
\hline
\end{tabular}

adalah $1,0 \times 10^{5} \mathrm{cfu} / \mathrm{g}$. Kandungan BAL pada growol yang terbuat dari ubikayu varietas Meni, Ketan, dan Lanting adalah $1,5 \times 10^{6}-2,9 \times 10^{7}$. Perbedaan jumlah BAL tersebut disebabkan kadar pati ketiga varietas ubi kayu berbeda, yaitu berkisar 30,19 $\pm 3,43 \%-35,86 \pm 2,21 \%$ (bk) atau $10,71 \pm 1,21 \%-16,85 \pm 1,21 \%$ (bb), sedangkan pati merupakan substrat BAL, sehingga jumlah bakteri asam laktat yang terkandung didalamnya juga berbeda. Jumlah BAL tertinggi adalah pada growol yang terbuat dari ubi kayu varietas Lanting sebanyak $2,9 \times 10^{7} \mathrm{cfu} / \mathrm{g}$. Tingginya jumlah bakteri asam laktat (BAL) tersebut karena kadar pati ubi kayu varietas Lanting tinggi yaitu $16,85 \pm 1,24 \%$ (bb) atau 35,61 $\pm 2,53 \%$ (\%bk).

\section{Hasil Uji Kesukaan terhadap Growol}

Uji kesukaan merupakan respon dari panelis yang berupa penilaian terhadap produk yang disukai atau tidak disukai. Uji tersebut dilakukan pada growol untuk mengetahui tingkat kesukaan panelis. Hasil uji kesukaan disajikan pada Tabel 6.

Pengujian tingkat kesukaan terhadap warna, aroma, tekstur (kelunakan), rasa, dan kesukaan keseluruhan growol menggunakan skala penilaian dengan menggunakan angka 1 sampai 7. Nilai 1 menunjukkan kategori sangat suka dan nilai 7 sangat tidak suka.

Warna menentukan tingkat penerimaan suatu makanan. Dari hasil uji kesukaan diketahui bahwa varietas ubi kayu dan lama fermentasi berpengaruh nyata utamanya warna growol dari varietas Lanting. Hal ini kemungkinan panelis menganggap warna growol dari ubi kayu varietas Meni dan Ketan hampir sama putih sesuai warna khas growol, sedangkan pada growol dari varietas Lanting warnanya agak kuning. Selain warna, aroma growol berperan dalam menentukan kesukaan. Menurut (Anggraini dan Widawati, 2015), lama fermentasi akan membuat rasa dan aroma yang semakin asam. Aroma growol dihasilkan oleh kerja bakteri asam laktat (BAL) yang berperan untuk menimbulkan aroma asam, sehingga semakin lama fermentasi semakin asam dan kurang disukai.

Tekstur merupakan sensasi tekanan yang dapat diamati dengan mulut (ketika digigit, dikunyah, dan ditelan) ataupun perabaan menggunakan jari (Kramer dan Twigg, 1970). Dari hasil uji kesukaan pada Tabel 6 diketahui bahwa varietas ubi kayu dan lama fermentasi tidak berpengaruh nyata terhadap tekstur (kelunakan) growol yang dihasilkan. Tekstur growol terutama ditentukan oleh kadar airnya. Kadar air growol antara $55,84-64,37 \%$ ternyata tidak memberikan perbedaan kesukaan terhadap tekstur. Hasil penelitian sebelumnya juga mendapatkan bahwa kadar air growol antara 
Tabel 6. Tingkat kesukaan growol

\begin{tabular}{lcccccc}
\hline Varietas & $\begin{array}{c}\text { Fermentasi } \\
\text { (hari) }\end{array}$ & Warna* & Aroma* & $\begin{array}{c}\text { Tekstur } \\
\text { (kelunakan)** }\end{array}$ & Rasa* & Keseluruhan* \\
\hline Meni & 2 & $2,76 \pm 1,27^{\mathrm{a}}$ & $2,72 \pm 1,14^{\mathrm{a}}$ & $2,60 \pm 1.29$ & $2,72 \pm 1,40^{\mathrm{a}}$ & $2,64 \pm 1,15^{\mathrm{a}}$ \\
& 4 & $2,76 \pm 1,51^{\mathrm{a}}$ & $3,28 \pm 1,43^{\mathrm{ab}}$ & $3,56 \pm 1,47$ & $3,72 \pm 1,62^{\mathrm{b}}$ & $3,32 \pm 1,46^{\mathrm{ab}}$ \\
\multirow{2}{*}{ Ketan } & 2 & $2,92 \pm 0,91^{\mathrm{a}}$ & $3,76 \pm 1,54^{\mathrm{b}}$ & $3,12 \pm 1,39$ & $2,72 \pm 1,21^{\mathrm{a}}$ & $3,16 \pm 1,21^{\mathrm{ab}}$ \\
& 4 & $2,84 \pm 1,14^{\mathrm{a}}$ & $2,40 \pm 1,47^{\mathrm{a}}$ & $3,44 \pm 1,69$ & $4,04 \pm 1,67^{\mathrm{b}}$ & $3,56 \pm 1,53^{\mathrm{b}}$ \\
\multirow{3}{*}{ Lanting } & 2 & $2,44 \pm 1,16^{\mathrm{a}}$ & $4,08 \pm 1,55^{\mathrm{b}}$ & $3,28 \pm 1,86$ & $3,36 \pm 1,70^{\mathrm{ab}}$ & $3,28 \pm 1,49^{\mathrm{ab}}$ \\
& 4 & $3,88 \pm 1,45^{\mathrm{b}}$ & $4,00 \pm 1,78^{\mathrm{b}}$ & $3,44 \pm 1,58$ & $4,08 \pm 1,41^{\mathrm{b}}$ & $3,92 \pm 1,41^{\mathrm{b}}$ \\
\hline
\end{tabular}

* huruf yang berbeda dibelakang angka pada kolom yang sama menunjukkan berbeda nyata pada $a=0,05$

**tidak signifikan

$54,63-60,03 \%(\mathrm{bb})$, sehingga tekstur growol tidak berbeda nyata.

Hasil uji kesukaan rasa diketahui bahwa varietas ubi kayu dan lama fermentasi berpengaruh nyata pada tingkat kesukaan panelis terhadap rasa growol yang disajikan. Rasa khas growol adalah asam. Semakin lama waktu fermentasi, semakin banyak pula kandungan bakteri asam laktat dalam growol, sehingga menyebabkan timbulnya rasa asam (kecut) pada growol dan ternyata malah kurang disukai. Hasil ini sesuai yang dilakukan oleh (Setiawan dkk., 2013) yang menyatakan bahwa fermentasi akan menghasilkan asam. Pada Tabel 4 tampak bahwa nilai keasaman tertitrasi growol menunjukkan pengaruh yang nyata, dan $\mathrm{pH}$ growol juga terjadi penurunan seiring lama fermentasi, hal ini ternyata mempengaruhi rasa growol secara inderawi kurang disukai. Growol yang disukai adalah yang dibuat dari ubikayu varietas Meni yang difermentasi selama 2 atau 4 hari, atau varietas Ketan dan Lanting yang difermentasi selama 2 hari. Namun secara keseluruhan growol yang disukai adalah yang dibuat dari ubikayu Meni, karena warna, aroma dan rasa agak manis, sedangkan pada Lanting warna agak kekuningan, rasa masam dan tekstur agak keras.

\section{KESIMPULAN}

Berdasarkan hasil penelitian dapat disimpulkan bahwa varietas ubikayu dan lama fermentasi berpengaruh terhadap karakteristik dan tingkat kesukaan growol. Secara khusus kesimpulannya adalah growol yang disukai adalah growol yang dibuat dari ubikayu varietas Meni dengan lama fermentasi 2 dan 4 hari dan varietas Ketan dan Lanting dengan fermentasi selama 2 hari. Namun berdasarkan kandungan bakteri asam laktatnya, maka sebaiknya growol dibuat dengan varietas Meni dengan fermentasi selama 4 hari. Growol

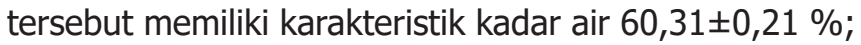

keasaman tertitrasi $0,40 \pm 0,05 \%$ dan kandungan bakteri asam laktat $1,5 \times 10^{6} \mathrm{cfu} / \mathrm{g}$.

\section{UCAPAN TERIMA KASIH}

Terima kasih kepada Direktorat Riset dan Pemberdayaan Masyarakat, KemenristekDikti atas dana yang telah diberilkan melalui Program Penelitian Unggulan Perguruan Tinggi pada Tahun 2019 dengan Surat Perjanjian Kontrak No. 227/SP2H/LT/DRPM/2019 tanggal 11 Maret 2019.

\section{KONFLIK KEPENTINGAN}

Penulis menyatakan bahwa tidak ada konflik kepentingan antar penulis atau dengan pihak lain dalam penulisan artikel ini.

\section{DAFTAR PUSTAKA}

Adesokan, I. A., B. B. Odetoyinbo, Y. A. Ekanola, R. E. Avanrenren dan S. Fakorede. 2011. Production of Nigerian nono using lactic starter cultures. Pakistan Journal Nutrition. 10(3): 203-207.

Afriani, A. 2010. Pengaruh penggunaan starter bakteri asam laktat Lactobacillus plantarum dan Lactobacillus fermentum terhadap total bakteri asam laktat, kadar asam dan nilai $\mathrm{pH}$ dadih susu sapi. Jurnal Ilmu-Ilmu Peternakan. 13 (6): 279-285.

Amarullah, Indradewa, Yudono dan Sunarminto. 2016. Evaluasi Kualitas dan Hasil Tiga Varietas Ubi Kayu. Prosiding Seminar Hasil Penelitian Tanaman Aneka Kacang dan Umbi 2016. http://balitkabi.litbang.pertanian.go.id/wpcontent/uploads/2017/07/pros16_61.pdf. Diunduh pada tanggal 16 Februari 2020.

Anggraini, dan L. Widawati. 2015. Pengaruh Waku Fermentasi Tempoyak terhadap Sifat Organoleptik Sambal Tempoyak. Agritepa. 2(1):118-127. 
Anonim. 2017. Deskripsi varietas unggul ubi kayu. 19782016. http://balitkabi.litbang. pertanian.go.id/wp-content/ uploads/2016/09/ubikayu.pdf

AOAC. 1970. Official Methods of Analysis of The Association of Official Analytical Chemists. Association of Official Analytical Chemists, Washington, D. C.

Apriyantono, A., D., Fardiaz, N. P., Sedarnawati dan S. Budiyanto. 1989. Analisis Pangan.PAU Pangan dan Gizi,IPB.

Ariani, L.N., T. Estiasih dan E. Martati. 2017. Karakteristik Sifat Fisiko Kimia Ubi Kayu Berbasis Kadar Sianida. Jurnal Teknologi Pertanian. 18(2):119-128.Augustyn, G., Polnaya, F., \& Parinusa, A. (2007). Karakterisasi Beberapa Sifat Pati Ubi Kayu (Manihot esculenta, Crantz). Buletin Penelitian BIAM, 3, 35-39.

Augustyn, G.H., F.J. Polnaya dan A. Parinusa. 2007. Karakterisasi Beberapa Sifat Pati Ubi Kayu (Manihot esculenta, Crantz).https://www.researchgate.net/ publication/298071893_ Karakterisasi_Beberapa_Sifat_ Pati_Ubi_Kayu_Manihot_esculenta_Crantz. [accessed Jul 27 2019].

Bangsa, D. 2015. KulonProgo Tempo Dulu. www.kotawates. com/growol-citarasa-kulon-progo-tempo-dulu.html. Downloaded on August 11, 2017.

FAO/WHO. 2002. Joint FAO/WHO Working Group Report on Drafting Guidelines for the Evaluation of Probiotics in Food. London.

Fardiaz, S. 1992. Mikrobiologi Pangan I. Jakarta: PT. Gramedia Pustaka.

2. Kasaai, M.R. 2014. Use of Water Properties in Food Technology: A Global View. International Journal of Food Properties. 17(5): 1034-1054. https://www.tandfonline. com/doi/pdf/10.1080/10942912.2011.650339?needAcc ess=true. Diunduh pada tanggal 18 Februari 2020.

Komesu, A., P.F.M. Martinez, B.H. Lunelli, J. Oliveira, M.R.W. Maciel, dan R.M. Filho. 2017. Study of Lactic Acid Thermal Behavior Using Thermoanalytical Techniques. Journal of Chemistry. 1-7. https://www.hindawi.com/ journals/jchem/2017/4149592/

Krammer, A.A. dan Twigg, B.A. 1966. Fundamental of quality control for the food industry. Westport, Connecticut: the AVI Publishing Company, Inc. Retrieved from file:// catalog.hathitrust.org/Record/001043255

Lestari, L.A. 2009. Potensi Probiotik Lokal Sebagai Makanan Fungsional Pencegah Diare. http://gizikesehatan. ugm.ac.id/2009/06/potensi-probiotik-lokal-sebagaimakanan-fungsional-pencegah-diare/. Diunduh pada tanggal 22 Maret 2017.
Murtiningrum, Bosawer,E.F., Istalaksana, P. dan Jading, A. 2012. Karakterisasi Umbi dan Pati Lima Kultivar Ubi Kayu (Manihot esculenta). Jurnal AGROTEK . 3(1): 81-90.

Putri, W.D.R, Haryadi, Marseno, D.W., Nur Cahyanto, M. 2012. Isolation and Characterization of Amylolytic Lactic Acid Bacteria during Growol Fermentation, an Indonesian Traditional Food, Jurnal Teknologi Pertanian Vol. 13 , 1 : 52-60.

Advances26: 22-34..

Setiawan, N. Yuliana, dan S. Setyani. 2013. Pengaruh Konsentrasi Garam terhadap Warna, Total Asam dan Total Bakteri Asam Laktat Pikel Ubi Jalar Ungu (Ipomoea batatas var Ayamurasaki) Selama Fermentasi. Jurnal Teknologi Industri dan Hasil Pertanian. 1(18):42-52.

Setyaningsih, D., A. Apriyantono dan M. P. Sari. 2010. Analisis Sensori untuk Industri Pangan dan Agro. Institut Pertanian Bogor Press, Bogor

Susilawati, A., S. Nurjanah dan S. Putri. 2008. Cassava (Manihot esculenta) physical and chemical properties of different plantation location and harvesting ages. Journal of Industrial Technology and Agricultural Products 13(2): 59-72.

Wariyah, Ch. dan S. Luwihana. 2015. Improvement of Growol as a Probiotic-Functional Food (Case Study at Kalirejo, Kokap, Kulon Progo, DIY), 150-156.

Wariyah,Ch., Riyanto., Kanetro,B. 2018. Effects of Fermentation Duration and Cooking Method on the Chemical Properties and Acceptability of Growol. Proceeding on the 2nd International Conference on Natural Resources Biotechnology : From Local to Global. July 13th - 14th 2018, Faculty of Biotechnology - Universitas Atma Jaya Yogyakarta, Yogyakarta - Indonesia.

Williams, P. C., Kuzina, F. D., and Hlynka, I. 1970. A rapid colorimetric procedure for estimating amylose content of starches and flours. Cereal Chemistry 47(-):411-420.

Yuniastuti, A. 2014. Probiotik (Dalam Perspektif Kesehatan). UNNES Press. Semarang.

Zhu, L., Ma, T., Mei, Y. and Li, Q. 2017. Enhancing the hydrolysis of corn starch using optimal amylases in a high-adjunct-ratio malt mashing process. Food Sci Biotechnol. 26(5): 1227-1233. https://www.ncbi.nlm. nih.gov/pmc/articles/PMC6049791/ 